\title{
Quantifying impacts of agro-industrial expansion in Mato Grosso, Brazil, on watershed hydrology using the Soil and Water Assessment Tool (SWAT) model
}

\author{
$\underline{\text { A.C. Guzha }}^{\mathrm{a}}$, R. Nobrega ${ }^{\mathrm{a}}$, K. Kovacs ${ }^{\mathrm{a}}$, R.S.S. Amorim ${ }^{\mathrm{b}}$ and G. Gerold ${ }^{\mathrm{a}}$ \\ a. Department of Landscape Ecology. Georg-August University, Gottingen, GERMANY \\ b. Faculdade de Agronomia, Medicina Veterinária e Zootecnia. UFMT Avenida Fernando Corrêa, $N^{\circ} 2367$ - \\ Boa Esperança, Cuiabá-MT 78060-900, BRAZIL \\ alphonce-c.guzha@geo.uni-goettingen.de
}

\begin{abstract}
Problem Statement: Dynamically changing Land Use and Land Cover (LULC) in the tropics may significantly affect catchment hydrology with implications for the management of river basins. It is, however, unclear how future changes will impact water related ecosystem services. The results presented in this study are part of the CarBioCial project in Southern Amazonia which aims at monitoring and quantifying catchment water balances and associated carbon cycling within a dynamic landscape context. Based on predictive modeling the project also aims to investigate how far changes in climatic regimes and LULC can impact the provision of water related ecosystem services such as water quantity, quality, and distribution as well as carbon storage and sequestration at the local and regional level. The methods and results presented in this paper are a preliminary investigatory assessment of the inter-relationship between LULC and catchment hydrology.

Approach: We apply the Soil \& Water Assessment Tool (SWAT) model, to evaluate hydrological responses for different LULC change scenarios (deforestation, cropland, cerrado and pasture expansion) in the Rio Das Mortes watershed in Mato Grosso, Brazil. General input data such as topography, soil and land use data were used to run SWAT and the model was calibrated and validated using discharge data measured at two gauging stations in the watershed. The Sequential Uncertainty Fitting (SUFI-2) algorithm in SWAT-CUP was used for model calibration and validation. To assess the impacts of land cover changes on watershed hydrology, the calibrated model was applied to scenarios of LULC within this watershed. Results of water balance simulations are presented taking into account the effects of different rainfall patterns.

Results: Generally, the model performed satisfactorily, indicated by values greater than 0.75 for Nash-Sutcliffe (NS) and the coefficient of determination $\left(\mathrm{R}^{2}\right)$ for two gauging stations in the study watershed during the calibration period (1986-1995). For selected likely future land cover scenarios including conversion of pasture to cropland, simulation results showed that land use changes result in corresponding increases in surface runoff and water yield (4-8\%) and decreases in evapotranspiration, soil water infiltration and base flow (5-13\%). Increased water yields however are not sustained in the dry season as shown in the flow duration curves. The results indicate that land cover changes to agriculture activities is likely to reduce dry season flows and increase peak flows in the wet season. Reduced dry season flows may lead to greater water scarcity at critical times of the year while increased peak flows may lead to enhanced soil erosion and thus impact on water revision in the watershed.

Conclusions: This research has successfully utilized the semi distributed SWAT model to evaluate how catchment hydrologic fluxes including water yield might be impacted by anthropogenic changes associated with LULC dynamics. Future work includes applying the calibrated model in different long term climatic scenarios and also to use the model for prediction in ungauged catchments by applying it to a meso-scale catchment within the study watershed where there are no discharge data available for model calibration. This multi-scale approach will be used as it allows quantification of scale-specific signatures for the simulation of land management induced changes in water balance components at a local scale.
\end{abstract}

Keywords: Land Use Land Cover Change, Watershed Hydrological Response, Alternative Scenarios, SWAT model 


\section{INTRODUCTION}

Increasing population and land cover changes are complicating watershed-scale prediction by placing additional uncertainty on future water resource conditions. In the Amazon, conversion of forest to pasture results in increased frequency and volume of overland flow (Germer et al., 2009; Zimmermann et al., 2006). Soil compaction induced by deforestation increases bulk density and penetration resistance and reduces macro porosity, infiltration rates and hydraulic conductivities leading to increased discharge (Martínez and Zinck, 2004). The magnitude and duration of land use change effects on stream flows is influenced by soils, morphology and geology of the catchment, rainfall characteristics and patterns and type of forest operations and the type of the vegetation established after the deforestation (Birkinshaw et al, 2010). Despite these various studies, as stated by Germer et al. (2009), further research could provide insight into the relationship of stream discharge volume increases due to land-use change and deforestation on different soils and at different scales.

The concept of ecosystem service provision has become a method for promoting sustainable management of natural resources, including water. Ecosystem services are the benefits people obtain from ecosystems. While a key issue of the ecosystem service concept has been the methods and criteria for quantifying the provided ecosystem service, any quantification approach should also provide the possibility of predicting service availability for future scenarios. Thus, the main objective of this study was to assess the temporal dynamics of watershed water balance components such as stream flow, evapotranspiration and base flow and how they are influenced by changes in land cover in a watershed in Mato Grosso state, Brazil. In this study, we (1) test the applicability of the SWAT model in a tropical watershed of Brazil using GCM weather data, and (2) explore the relative influence of LULC changes on watershed discharge and their impacts on simulated streamflow, which can be used as an indicator for fresh water provision ecosystem service. To achieve these objectives, the following steps were taken:

1. Use available limited data to optimize input datasets by combining information from different sources.

2. The Soil and Water Assessment Tool (SWAT) was set up as hydrological simulator and calibrated at the monthly time step using Sequential Uncertainty Fitting ver. 2 (SUFI-2) (Abbaspour et al., 2007).

3. Quantitative indicators for water yield and water balance for selected land cover options in the study watershed were derived from model results.

\section{STUDY AREA DESCRIPTION}

The study was conducted in the Rio Das Mortes watershed (Figure 1) located in Mato Grosso State, Brazil. The watershed, located between $53^{\circ} 45^{\prime}$ and $55^{\circ} 30^{\prime} \mathrm{W}$, and $14^{\circ} 45^{\prime}$ and $16^{\circ} 00^{\prime} \mathrm{S}$, covers an area of $17,555 \mathrm{~km}^{2}$. The study area is in the western part of the Central Brazilian Plateau and has mostly flat to very gently undulating and elevation varies from $336 \mathrm{~m}$ in the lowlands along the rivers to $908 \mathrm{~m}$ with slopes predominantly in the $1-5 \%$ range. The main soil types are the latossolo vermelho, latossolo vermelho-amarelo and latosso amarelo (Brazilian classification) covering almost $70 \%$ of the watershed.

Land-use is predominantly agricultural and it is one of the principal production areas of grain and cotton in Mato Grosso State with annual

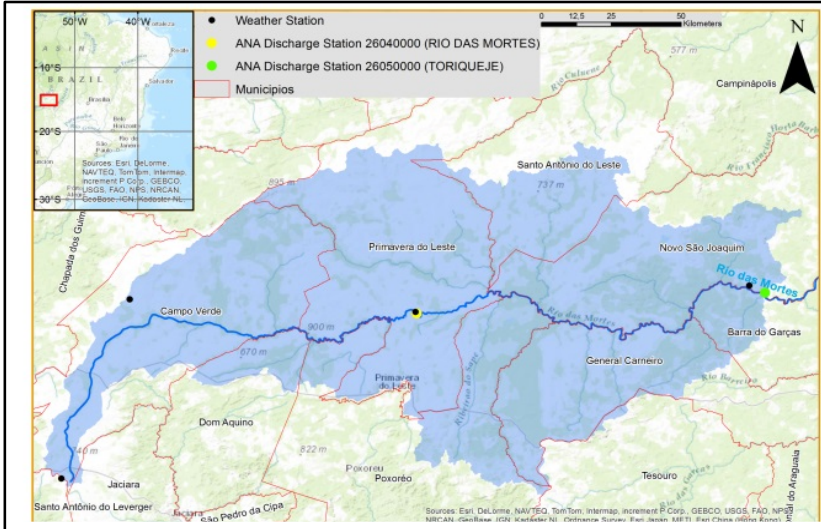

Figure 1. The Upper Rio Das Mortes Watershed in Mato Grosso, Brazil production of maize, cotton and soybeans. Natural vegetation remains only in patches and along the rivers and is dominated by the Cerrado (savanna) and gallery forests. The average annual rainfall in this region is about $1600 \mathrm{~mm} /$ year and the Rio Das Mortes River is characterized by a pronounced seasonal flow regime showing a yearto-year variability with high flows during summer period (November to April) and low flows occur during the dry season (May to October.)

\subsection{Climate data}

Climatic data are sparse for this study watershed. The re-analysis data predictands of the National Center of Environmental Prediction (NCEP) on HadCM3 computational grid for 1980-2010 were used in this study. The data were obtained from the Soil and Water Assessment Tool (SWAT) website (http://swat.tamu.edu/). The data includes 
precipitation, solar radiation, relative humidity, wind speed and minimum and maximum temperature. To test the effects of different rainfall patterns we, used the calibrated model for time periods in which annual rainfall was below long term average $(1400 \mathrm{~mm} /$ year $)$ and also a time period in which the average rainfall was above the long term average $(1800 \mathrm{~mm} / \mathrm{year})$.

\subsection{River Discharge}

There are two gauging stations (ANA 26040000 and ANA 26050000) with long term historic discharge records in the Rio Das Mortes watershed. Discharge data from these stations were used for model calibration and validation. Table 1 shows the locations of these gauging stations and the available data records.

Table 1. Stream flow gauging stations in the study watershed and available data records

\begin{tabular}{lllllll}
\hline Station Code & Name & River & State & Location & Established date & Record \\
\hline $\mathbf{2 6 0 4 0 0 0 0}$ & Rio Das Mortes & Das Mortes & MT & $-151853-541033$ & $01 / 04 / 1976$ & $1968-2007$ \\
$\mathbf{2 6 0 5 0 0 0 0}$ & Toriqueje & Das Mortes & MT & $-151455-530319$ & $01 / 12 / 1967$ & $1968-2007$ \\
\hline
\end{tabular}

\subsection{The Soil Water Assessment Tool (SWAT) model}

SWAT is a continuous, physically based, semi-distributed hydrologic model developed by the USDA-Agricultural Research Service and the Texas Agricultural Experiment Station. The model calculates and routes water, sediments and contaminants from individual drainage sub-basins towards the outlet and has been widely used to predict the impact of management practices on water, nutrient and sediments in basins with varying soils, land use and management conditions (Arnold and Fohrer, 2005). The simulation of the watershed's hydrological cycle is divided into two phases: the land phase and the routing phase. For modeling the land phase, the river basin is divided into sub-basins, which can be further subdivided into one or several Hydrological Response Units (HRUs). HRUs are areas of relatively homogeneous LULC and soil types. The characteristics of the HRUs define the hydrological response of a sub-basin. For a given time step, the contributions to the discharge at each sub-basin outlet point is controlled by the HRU water balance calculations (land phase). The river network connects the different sub-basin outlets, and the routing phase determines movement of water through this network towards the basin outlet (Neitsch et al., 2005).

\subsection{Parameterization, Calibration and Verification of SWAT}

In our study, we used the SWAT2012 version and the model was calibrated using the split sample approach with measured discharge data. Measured discharge data for the period from 1985 to 1995 was used for model calibration while data for the period 1996-2001 was used for model validation. The watershed was discretized into 37 sub-basins and HRUs were generated based on dominant land cover, soil and slope. Data for the SWAT set up were prepared using Microsoft Excel 2010 and ESRI ArcGIS®. Topographic data were obtained from ASTER Global DEM V2 datasets and soil data were obtained from RADAMBRASIL databases.

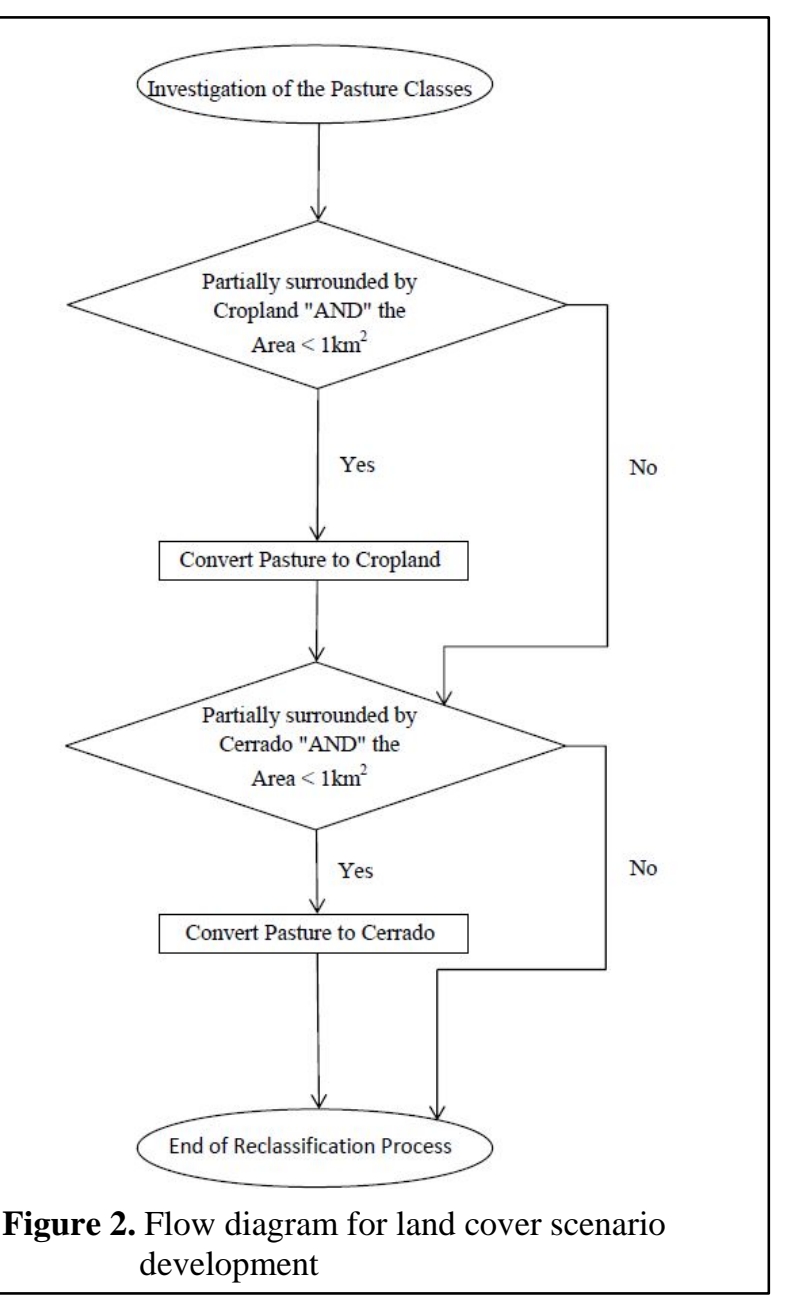

\subsection{Land Cover Scenarios}

Two land cover scenarios were selected for impact analysis with SWAT. These scenarios are based on likely future changes of land cover in the watershed as dictated by economic drivers such as value of crops and depreciation in value of livestock. As stated by Morton et al. (2006), the rise and fall of profits for different crops, beef, plantation timber, and other resources will determine future land use on both new deforestation and previously cleared areas. The two land cover scenarios of the study watershed were created from LANDSAT imagery from the 2009-2012 
time series by raster reclassification in ESRI ArcGIS ${ }^{\circledR}$ Software. Figure 2 shows the work flow diagram for the generation of the land cover for scenario 1 . In this scenario, the modification process followed the actual agricultural developments and land cover changes of the last years within the study area. The small pastures surrounded by cropland have been converted into cropland. Other small pastures have become uncultivated areas. For this reason, the increase of the cerrado vegetation could be noted.

In scenario 2, all pasture areas were converted into cropland. After these raster calculations, all cerrado land use categories were transformed into pasture. Figure 3 shows the base case scenario and the two generated land cover scenarios. Using these land cover scenarios, SWAT model runs were performed and only model parameters that were defined by the land use map were different in the model setups.

\section{RESULTS AND DISCUSSION}

\subsection{Model Calibration and validation}

During model calibration, a one year warm up period was used to reduce any influence of initial conditions in the model results. Model parameters were varied in order to fit the modeled streamflow to the measured streamflow at the two gauging stations. A sensitivity analysis was used to reduce the number of parameters to be adjusted during calibration. The main calibration parameters were curve number (CN2), soil available water capacity (SOL_AWC), soil evaporation compensation factor (ESCO), saturated hydraulic conductivity (SOL_K), groundwater "revap", (GW_REVAP) and baseflow alpha factor (ALPHA_BF). Figures 4 and 5 and table 2 show the results of model calibration and validation Within the limits of the calibration parameter range, generally and based on the summary statistics in Table 1, the model is considered acceptable for use in evaluating results from different alternative scenarios such as land cover.

Different combinations of parameter sets also yielded relatively similar NS values indicating that there was no unique parameter estimation and hence uncertainty in the estimated model parameters exists. This may be due to the fact that parameters obtained from calibration were affected by several factors such as correlations amongst parameters, sensitivity or insensitivity in parameters.

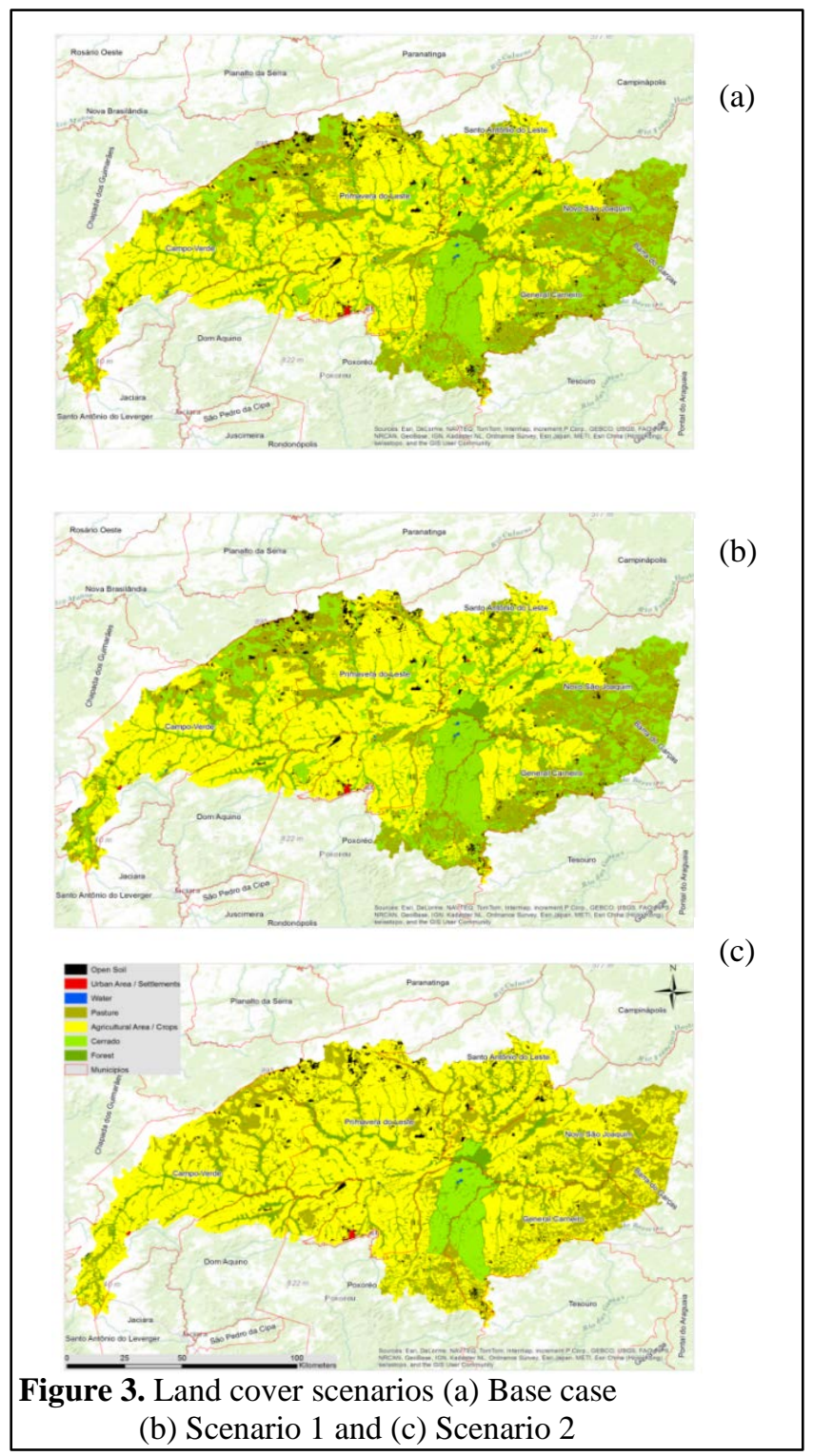

Table 2. Summary statistics for model calibration and validation

\begin{tabular}{|l|lcccc|}
\hline \multicolumn{2}{|c}{ Discharge Station } & $\mathrm{R}^{2}$ & $\mathrm{NS}$ & $\begin{array}{c}\text { Mean measured } \\
\text { discharge }\left(\mathrm{m}^{3} / \mathrm{s}\right)\end{array}$ & $\begin{array}{c}\text { Mean modeled } \\
\text { discharge }\left(\mathrm{m}^{3} / \mathrm{s}\right)\end{array}$ \\
\hline$\underline{\text { Calibration }}$ & Rio Das Mortes & 0.81 & 0.63 & 127 & 148 \\
& Toriqueje & 0.82 & 0.58 & 389 & 418 \\
\hline$\underline{\text { Validation }}$ & Rio Das Mortes & 0.60 & 0.51 & 116 & 137 \\
& Toriqueje & 0.50 & 0.48 & 374 & 401 \\
\hline
\end{tabular}




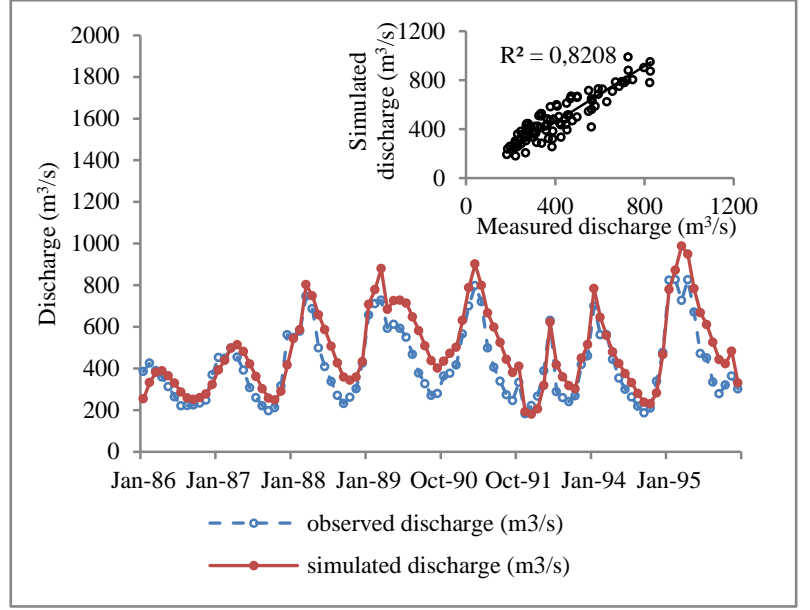

a)

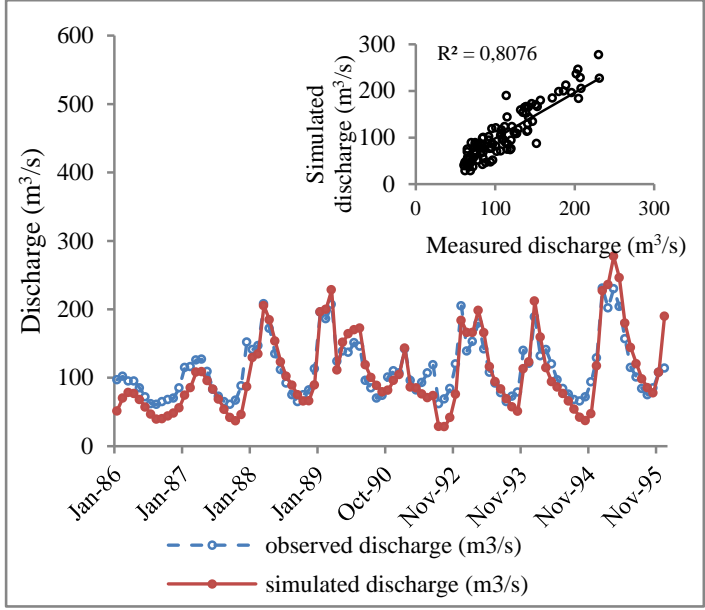

(b)

Figure 4. Measured and simulated discharge at two gauging stations (a) Toriqueje and (b) Rio Das Mortes for model calibration period

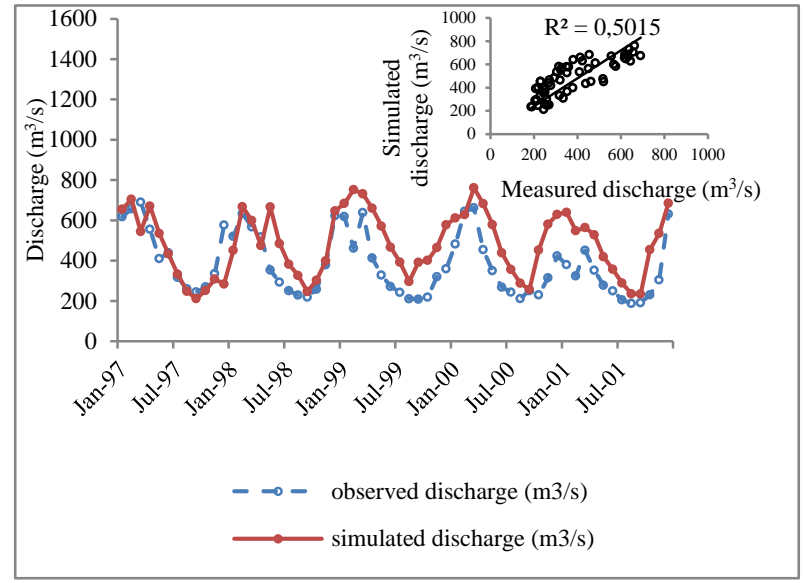

(a)

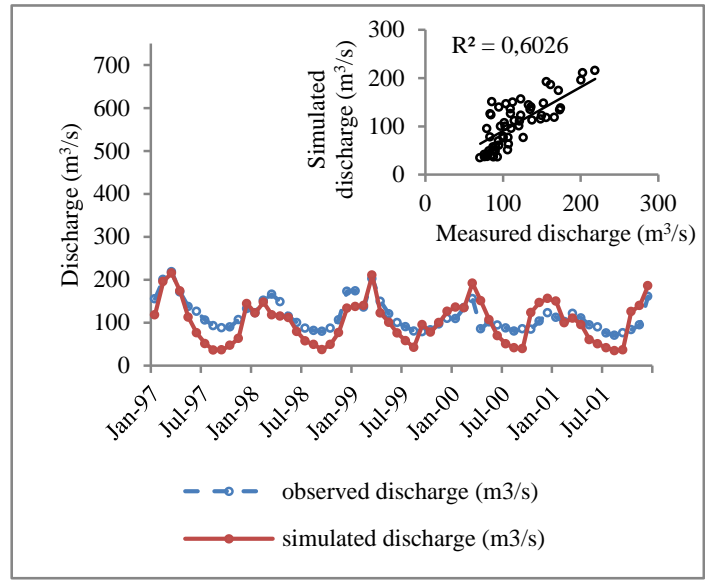

(b)

Figure 5. Measured and simulated discharge at two gauging stations (a) Toriqueje and (b) Rio Das Mortes for model validation period

\subsection{Effects of land cover changes based on selected scenarios}

Table 3 shows the simulated impacts of land cover changes on Water Yield (WYLD) for the study watershed. WYLD is a summation of surface runoff, lateral subsurface flow, and baseflow. Changes in long-term mean annual water yield range from $+4 \%$ to $+7 \%$. Increased water yields and decrease in evapotranspiration due to land cover changes and deforestation were also found in other studies (e.g., Im et al., 2009; Wijesekara et al., 2012).

For scenario 2, the incremental decrease of the cerrado and increase of pasture and crop land leads to a decrease in the Leaf Area Index and Root depths values relative to scenario 1 . This in turn results in a decrease of evapotranspiration. However, these impacts on water yield may not be very high $(<10 \%)$ relative to the agricultural expansion in the study watershed. This could be attributed to the rainfall pattern in the watershed. Heavy rainfalls in the study watershed often exceed the infiltration capacity of the soil, leading to
Table 3. Simulated changes in water yield (WYLD), at watershed outlet for different land cover scenarios and rainfall patterns

\begin{tabular}{|c|c|c|c|}
\hline$\underline{\text { Scenario }}$ & $\frac{\text { PRECIP }}{(\mathrm{mm})}$ & $\frac{\text { WYLD }}{(\mathrm{mm})}$ & $\begin{array}{l}\text { \% Change in } \\
\text { WYLD }\end{array}$ \\
\hline Baseline & & 1237 & \\
\hline 1 & 2024 & 1280 & $3 \%$ \\
\hline 2 & & 1288 & $4 \%$ \\
\hline Baseline & & 815 & \\
\hline 1 & 1484 & 860 & $6 \%$ \\
\hline 2 & & 873 & $7 \%$ \\
\hline
\end{tabular}


Hortonian surface runoff. To identify differences in hydrological processes with various types of land use, we summarized the water balance associated with land use types using annual means. Table 4 summarizes simulated water balance components for the different land cover scenarios based on a five year simulation.

Table 4. Land cover changes effects on water balance relative to the

Results from this study indicate that ongoing land cover changes will result in less evapotranspiration and more runoff. In the mean annual water balance, this effect was caused by an increase of cropland in some areas of the catchment. However, the mean seasonal variation of runoff was changed, as land cover changes to cropland and urbanization resulted in more runoff in the base case scenario

\begin{tabular}{|llcc|}
\hline Water Balance & \multicolumn{3}{c|}{ Land Cover Scenario } \\
\cline { 2 - 4 } Component & Base Case & Scenario 1 & Scenario 2 \\
\hline ET (mm) & 1350 & 1249 & 1228 \\
ET change (\%) & & $-7 \%$ & $-9 \%$ \\
\hline Base flow (mm) & \multirow{6}{*}{550} & 615 & 615 \\
Base flow change (\%) & & $-5 \%$ & $-5 \%$ \\
\hline Infiltration (mm) & \multirow{2}{*}{398} & 362 & 345 \\
Infiltration change (\%) & & $-9 \%$ & $-13 \%$ \\
\hline
\end{tabular}

rainy season. Results from this study on increased runoff generation due to land cover changes agree with results obtained by Costa et al., 2003 and D'Almeida et al, 2007. However, the results from this study show relatively minimal changes in stream discharge for the different land cover scenarios. The effects of land cover changes on streamflow may be difficult to discern especially in such large catchments because of non-uniform land use, introduction of no-tillage systems since last 15 years, different stages of regeneration, and spatial variations in rainfall (Bruijnzeel, 2003; Siriwardena et al., 2006). The referred studies show no detectable vegetation change effects on stream flow from large catchments and this could be attributed to regeneration of cerrado patches and gallery forests (Schlicht, 2013) in the catchments that could offset the effects of deforestation on stream flow. As outlined by D'Almeida et al. (2007), the hydrological response to land cover changes is controlled by several factors, which are not simultaneously dominant at particular spatial scales. Different extents of land cover change are therefore, expected to induce distinct, possibly contrasting effects. It is therefore important to disaggregate the results obtained from this study to a hydrologic response unit level or sub-basin level to obtain clearer responses to land cover changes.

To evaluate the impacts of land covers changes on dry season flows, flow duration curves (FDC) were plotted for the discharges under the different land cover options (Figure 6). The FDC show that while observed increases in water yield could be attributed to increased surface runoff (discharge) in the high flow periods, these increases are not observed in the middle to lower discharge periods. These results show that land cover changes result in reduced dry season flows. The baseline scenario dry season flows are higher than the two land cover scenarios. As outlined by (Bruijnzeel, 1989), it is likely that for the base case scenario, more of the water infiltrates into the soil, rather than quickly running off. Some water that infiltrates flows into the ground in the rainy season may not reach the streams until the dry season. Thus, even though land cover changes resulted in relative increases in water yields, the total water available in the dry season is higher in the base case land cover scenario compared to the two scenarios representing increased cropland and pasture.

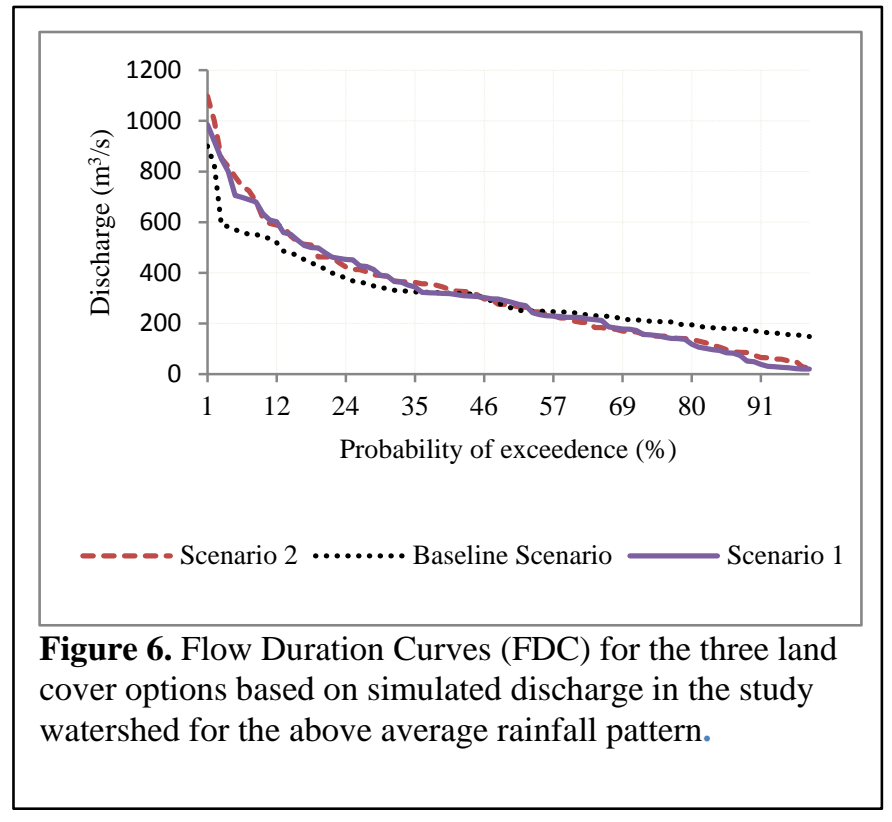

\section{CONCLUSIONS}

The SWAT model was parameterized and calibrated to simulate the effects of land use on runoff volumes and base flow. Results indicated that SWAT adequately predicts the runoff volumes and their temporal variation for the test watershed with NSE values ranging from 0.77 to 0.83 . LULC changes have been shown to have effects on hydrological processes in river basins. Watershed hydrologic processes including water yield and evapotranspiration were affected by land cover changes in the Rio Das Mortes watershed with water yield increases ranging from 4-7\% and ET decreases ranging from 7-9\%. Results of this study indicate that the water balance in the watershed might 
show greater changes under scenario 2 compared to the baseline scenario, which is plausible because scenario 2 is the extreme LULC change scenario. This study demonstrates the ability of integrating landscape spatial analysis with hydrological process models to evaluate potential future LULC at the watershed scale. A major drawback in the implementation of Payment for Ecosystem Service programs for land and water resources management is the lack of tools to quantify the ecosystem service. This study shows that spatial modeling using SWAT can be used to quantify water yield and relate this to provision of fresh water. The model can also be used as a tool to forecast the relative impacts of land cover changes for improved decision making for future land and water management. Ongoing research includes model uncertainty analysis and simulations using longer term predicted future climate scenarios.

\section{ACKNOWLEDGEMENTS}

The authors acknowledge the Bundesministerin für Bildung und Forschung (BMBF) for supporting this research through the CARBIOCIAL project (Support Code: 01LL0902A) and the Deutscher Akademischer Austausch Dienst (DAAD) scholarship support for Rodolfo Nobrega. The authors also acknowledge the collaboration of our research partners at the Federal University of Mato Grosso, and the Humboldt-University, Berlin. We also acknowledge the anonymous reviewers for their constructive comments, which helped us to improve the manuscript.

\section{REFERENCES}

Abbaspour, K.C., Yang J., Maximov I., Siber R., Bogner K, Mieleitner J., Zobrist J., and Srinivasan R. (2007). Spatially-distributed modeling of hydrology and water quality in the prealpine/alpine Thur watershed using SWAT. Journal of Hydrology, 333: 413-430.

Arnold J.G, and Fohrer N. (2005). SWAT2000: Current capabilities and research opportunities in applied watershed modeling. Hydrological Processes 19:563-572.

Birkinshaw, S.J., Bathurst, J.C.; Iroume, A. and Palacios, H. (2010). The effect of forest cover on peak flow and sediment discharge - an integrated field and modeling study in central-southern Chile. Hydrologic Processes. DOI: 10.1002/hyp.7900.

Bruijnzeel S. (1989). (De)forestation and Dry Season Flow in the Tropics: A Closer Look. Journal of Tropical Forest Science 1, pp. 229-243.

Bruijnzeel, L.A. (2004). Hydrological functions of tropical forests: not seeing the soil for the trees? Agriculture, Ecosystems \& Environment, 104 (1): 185-228.

Costa, M.H., Botta, A. and J. Cardille, J. (2003). Effects of large-scale changes in land cover on the discharge of the Tocantins River, Southeastern Amazonia. Journal of Hydrology, 283: 206-217.

D`Almeida, C., Vörösmarty, C.J., Hurtt, G.C., Marengo, J.A., Dingsman, S.L. and Keim, B.D. (2007). The effect of deforestation on the hydrological cycle in Amazonia: a review on a scale and resolution. Int. Journal of Climatology (27) 5, 633-647.

EMBRAPA (Empresa Brasileira de Pesquisa Agropecuária) (2006). Sistema brasileiro de classificação de solos. Brasília, DF: Embrapa Produção de Informação. Rio de Janeiro: Embrapa Solos, 412.

Germer, S., C. Neill, T. Vetter, J. Chaves, Krusche, A.V. and Elsenbeer, H. (2009). Implications of long-term land-use change for the hydrology and solute budgets of small catchments in Amazonia. Journal of Hydrology. 364(1-4), 349-363.

Martínez, L.J., and Zinck, J.A. (2004). Temporal variation of soil compaction and deterioration of soil quality in pasture areas of Colombian Amazonia. Soil and Tillage Research 75(1), 3-18, doi: 10.1016/j.still.2002.12.001.

Morton, D.C.; DeFries, R.S.; Shimabukuro, Y.E.; Anderson, L.O.; Arai, E.; Espirito-Santo, F.; Freitas, R. and Morisette, J. (2006). Cropland expansion changes deforestation dynamics in the southern Brazilian Amazon. Proceedings of the National Academy of Sciences (PNAS) 103 (39) 14637-14641

Neitsch S.L., Arnold J.G., Kiniry J.R., and Williams J.R. (2005). Soil and water assessment tool: Theoretical documentation, version 2005. Grassland \& Water Research Laboratory \& Blackland Research Center, Temple, TX

Schlicht, S. (2013). Dynamics of deforestation and agricultural production in the upper Rio das Mortes watershed in Mato Grosso state (Brazil), Unpubl. MSc thesis. University of Goettingen.

Siriwardena, L., Finlayson, B. L. and McMahon, T. A. (2006). The impact of land use change on catchment hydrology in large catchments: The Comet River, Central Queensland, Australia. Journal of Hydrology, 326, 199-214.

Wijesekara, N., Gupta, A., Valeo, C., Hasbani, J. G., Qiao, Y., Delaney, P., and Marceau, D. J. (2012). Assessing the impact of future land-use changes on hydrological processes in the Elbow River watershed in southern Alberta, Canada. Journal of Hydrology 2 412-413: 220-232.

Zimmermann, B., Elsenbeer, H. and Moraes, J.M. (2006). The influence of land-use changes on soil hydraulic properties: implications for runoff generation. Forest Ecology and Management 222(1-3), 29-38. 